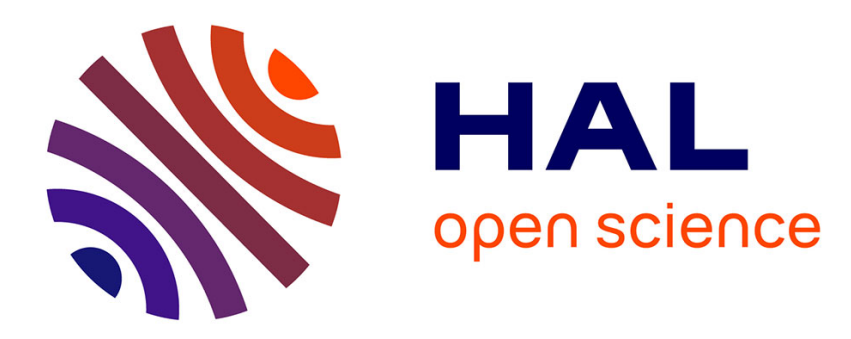

\title{
Unemployment Duration of Spouses: Evidence From France
}

\author{
Stefania Marcassa
}

\section{To cite this version:}

Stefania Marcassa. Unemployment Duration of Spouses: Evidence From France. 2011. halshs00588695

\section{HAL Id: halshs-00588695 \\ https://shs.hal.science/halshs-00588695}

Preprint submitted on 26 Apr 2011

HAL is a multi-disciplinary open access archive for the deposit and dissemination of scientific research documents, whether they are published or not. The documents may come from teaching and research institutions in France or abroad, or from public or private research centers.
L'archive ouverte pluridisciplinaire HAL, est destinée au dépôt et à la diffusion de documents scientifiques de niveau recherche, publiés ou non, émanant des établissements d'enseignement et de recherche français ou étrangers, des laboratoires publics ou privés. 


\title{
Unemployment Duration of Spouses: Evidence From France
}

\author{
STEFANIA MARCASSA*
}

\begin{abstract}
This paper presents the results of an econometric analysis of the conditional probability of leaving unemployment for four waves of French married men and women entering unemployment from 1991 to 2002. The effect of spouse's hourly earnings on unemployment duration is found to be asymmetric for men and women. In particular, an elasticity of 0.38 for men and -0.15 for women are found to be significant for the entire sample. Individual data from the French Labor Force Survey are used with accurate information on spell durations, and labor earnings of the spouses. Parametric estimation techniques are used.

Keywords: unemployment duration, hazard models, labor earnings, marriage, France JEL Classification: J12, J64
\end{abstract}

\section{Introduction}

The increasing level of unemployment both in Europe and in the U.S. is cause of output, income losses, and social costs. It is then important to understand the process that generates a certain level of unemployment. This process can be considered in terms of the probability of an individual entering unemployment, and the probability of an individual leaving unemployment. These probabilities vary with the characteristics of the individuals. In this paper, I will focus on the determinants of unemployment durations of married individuals.

*Paris School of Economics. Contacts: 48 boulevard Jourdan, Bâtiment A, Bureau 103, 75014 Paris. Office: +33 1431363 03, Fax: +331431363 55. Email: marcassa@pse.ens.fr 
The literature on job search provides numerous studies on the effect of wealth, unemployment benefit, and other characteristics on unemployment duration. ${ }^{1}$ One important point in these studies is that agents are assumed to be acting individually. But in a society where more than $60 \%$ of the agents are married or live in couples, it is important to consider how the individual's decisions depend on the characteristics of the partner.

We know that among the reasons that lead to marriage (or any other form of partnership), there is the possibility of sharing economic and social resources. ${ }^{2}$ In particular, marriage is seen as a sort of small insurance pool against life's uncertainties, reducing the spouses' need to protect themselves from unexpected events. Hence, during a period of unemployment, we could expect that the effort exerted to find a job by a married individual would depend on the spouse's income (other than on individual and local characteristics).

In this paper, I focus on French married men and women, and I find a significant elasticity of unemployment duration to spouse's earnings. But the effect is found to be asymmetric for men and women. In particular, an elasticity of 0.38 for men and 0.15 for women are found to be significant for the entire sample. In other words, while unemployment duration of married women increases with the husbands' earnings, the unemployment duration of married men decreases with wives' earnings. The econometric analysis is carried out with data from the French Labor Force Survey from 1991 to 2002.

This paper can be thought of as an empirical application of the first pioneering work on joint job-search by Burdett (1978) and the most recent work of Bulent, Guvenen, and Violante (2010). In the latter, the joint job-search and location problem of a couple who perfectly pools income is studied. They characterize the reservation wage behavior of the couple and compare it to the single-agent search model. They show that, in an environment where both spouses are risk averse, a dual searcher couple accepts job offers quickly (even quicker than a single agent). Once a worker-searcher

\footnotetext{
${ }^{1}$ There exists a vast literature on the relationship between unemployment duration and wealth, or unemployment benefit. An example is the seminal paper of Meyer (1990) who studies the individual behavior during the weeks just prior to the end of the unemployment insurance, and shows the negative effect of higher unemployment benefits on the probability of leaving unemployment. Danforth (1979) and Bloemen and Stancanelli (2001) shows that high levels of wealth result in lower probability of leaving unemployment, and higher reservation wages. Related works are from Lentz and Tranas (2005) and Lentz (2009) who have estimated empirically the optimal savings and job-search behavior of a risk averse worker as she moves back and forth between employment and unemployment, in order to determine the optimal unemployment benefit policy. A general study on the determinants of individual unemployment durations in Britain is provided by Arulampalam and Stewart (1995).

${ }^{2}$ An example is Waite (1995).
} 
couple, they become more choosy in accepting offers since the income pooling plays an insurance role. In my empirical analysis, I take spouse's earnings (and hence, spouse's employment status) as exogenous. However, as discussed in Bulent, Guvenen, and Violante (2010), the unemployment status of a spouse may affect the employment status of the partner. To control for this source of endogeneity, I instrument for spouse's earnings using the industrial sectors in which the spouse is currently working.

The results in this paper are partially in contrast with those of Arulampalam and Stewart (1995), where they examine the determinants of unemployment durations in Britain for two cohorts of men, 1978 and 1987. They find no significant marital status effect in the younger cohort, while I show that French married men have a significant higher probability of leaving unemployment than singles in all of the years included in the study. Moreover, they do not find a significant elasticity to wife's earnings.

I also provide evidence of the fact that the sub-sample of married men with children reacts differently to wives' earnings than those who are childless. ${ }^{3}$ While fathers' behavior is comparable to those of mothers, childless married men exit faster unemployment the higher the earnings of the wives. This can be related to the study of Solaz (2005), where she shows that when one of the two spouses is unemployed, the allocation of time devoted to household chores may change, and domestic tasks are organized according to a new, adjusted, specialization which is probably temporary. She focuses on the French case and tests the hypothesis of substitutability between partners. In particular, she compares different explanations of domestic work division during unemployment, whereby a person is forced by circumstances to perform additional domestic tasks. The paper shows that the employed partner does transfer to the unemployed partner some of the time (s)he devotes to domestic tasks. The tasks performed mainly by women are the most transferable: working partners transfer part of their share to the other partner if the latter loses his/her job. In contrast, unemployment does not reduce, and may even increase in the case of men, participation in mixed tasks. Hence, the reallocation of time towards the unemployed partner may affect her/his effort in searching for a job.

The approach followed here will be of an explorative nature. The impact of spousal's labor income on the hazard rate will be estimated using a reduced form approach. The data used are in the French Labor Force Survey. This paper is organized as follows. The description of the data is in Section 2. Next, in Section 3. I specify the empirical strategy. The results are presented in Section 4. Section 5 concludes.

\footnotetext{
${ }^{3}$ No difference is found for women.
} 


\section{Data Description}

The data used are from the Enquête Emploi, the French Labor Force Survey. Conducted by the INSEE (National institute of statistics and economics) since 1950, the Labor Force Survey is a longitudinal panel survey used to measure unemployment in the sense of the ILO (International Labor Organization).

In March of every year until 2002, members of around 65,000 French households are interviewed. One third of the household sample is renewed each year, such that a given individual is interviewed in three consecutive years. I use the data of those who entered in the survey in 1991, 1994, 1997, and 2000. Since 2003, the Labor Force Survey has been quarterly and the data has been collected from a sample of households on an ongoing basis each week in the course of the quarter. I do not include these later years in the analysis.

The survey provides information on the professions, on the activity of women and young people, working hours and casual employment. Moreover, extensive information is collected on the labor market behavior of individual respondents in the year preceding the moment of the interview. The respondents are asked to report the main labor market state ${ }^{4}$ they were in, for each month in that year, including the month of the interview. Some measurement errors may arise as a respondent who has worked less than $50 \%$ of the time in a month, may declare to be unemployed for the entire month. Also, a respondent may declare to be unemployed even if he is not registered as such at the public employment agency (Agence nationale pour l'emploi). By comparing individual labor market states of consecutive months in the periods from March 1990 to March 1993, March 1994 to March 1996, March 1997 to March 1999, and March 2000 to March 2002, individual unemployment durations can be constructed as a number of calendar months. Personal characteristics of the respondents are recorded at the first interview.

The initial and final number of individuals for the survey years used in the analysis are in Table 1. I select men and women older than 14 and younger than 60 years old, who are married or live in couple, and who reported inflow into unemployment at least once during the observation period form March 1990 to March 2002. I create an inflow sample of unemployment durations for spouses (husbands and wives) with available information on spouse's labor earnings and other characteristics. I only

\footnotetext{
${ }^{4}$ Respondents are asked to choose one among the following states: (1) employed for an unlimited period; (2) on his own or helping a family member in her activity; (3) fixed-term contracts, temporary job, training, seasonal work; (4) Vocational Training, or another paid internship (5) unemployed; (6) student, or unpaid internship; (7) military; (8) retired, early retirement, out of business, housewife, other.
} 
include spells starting within the mentioned period to avoid problems related to left censored observations.

The resulting unbalanced panel of four waves consists of 2,022 husbands and 3,616 wives. The former experience 2,091 unemployment spells, and the latter experience 3,175 unemployment spells. The maximum number of unemployment spells is 7 for men and 9 for women. These data are in Table 2 ,

At each interview, the respondents describe their labor market history of the past 12 months. Consider the following case. Two answers are available on the labor market state of March 1991 as the same question is asked retrospectively in the survey of 1992. Most of the studies that use the French Labor Force Survey data ${ }^{5}$ discuss the the existence of recall errors. I assume that if two answers on the labor market state in March differ, then the retrospective answer is incorrect and the most recent one is correct.

From the first interview in March 1991, March 1994, March 1997, and March 2000, I select a set of demographic characteristics that are assumed to be time-constant over the three years in which the individuals are followed. The labor earnings of the spouses are computed as the mean of the deflated hourly wages earned over the years in which the data are available ${ }^{6}$.

The wage of the wives is about $93 \%$ of that of husbands, evidence of a rather low gender wage gap in the samples. The set of characteristics contains indicator variables for living in the North, Center or South of France, having the French nationality, and being the owner of the house. The majority of the sample lives in the Northern and Center part of France, has French nationality, and about half of the households owns the real estate where the interview took place. This latter variable is the only available information on the wealth of the household. I also include the age at first interview, number of children (less than 18, 6, or 3 years old), and the number of years spent in school.

For the profession, I construct four categories (upper and lower managers, salaried and skilled workers), and include dummy variables for them. I also include dummy variables to control for the duration of unemployment spells of the spouse. More than $60 \%$ of unemployed women have husbands that have not been unemployed in

\footnotetext{
${ }^{5}$ See Lollivier (1994), Magnac (1994), and van den Berg and van der Klaauw (2001) for an extensive discussion.

${ }^{6}$ The hourly labor earnings of the spouses are computed from the monthly salary that includes non-monthly premiums, and divided by the usual hours worked in a month. In the cases in which the hourly wage is not higher than the minimum legal wage of that year, the hourly wage considered is the latter. See Table 5 for details on the minimum legal hourly wage, or salaire minimum interprofessionnel de croissance $(S M I C)$. In the empirical analysis, I consider the logarithm of the hourly wage.
} 
the time lag considered. If they were, the unemployment duration was less than six months. The percentage of unemployed men married to never unemployed women is slightly lower (50\%), but as above, the average unemployment duration was less than six months. In both samples, about half of the unemployed are registered to the national unemployment agency. Moreover, I distinguish two categories depending on the labor market state before entering unemployment: (1) inflow after permanent or temporary employment; (2) inflow after being a student, in the military or after any other non participation state. Men are mainly entering unemployment after a permanent job; women are mostly moving out from a state of inactivity. The regional unemployment rate is included as the average of the regional unemployment rate over the three years. The summary statistics are in Table 3 and 4.

\section{Specification of the Hazard Function}

I use the framework of a duration model to analyze exit from unemployment. In the French Labor Survey, job searchers are observed only once per month. For this reason, following Kiefer (1988) and Kuhn and Skuterud (2004), I develop and estimate a discrete time hazard model.

Suppose that there are $i=1, \ldots, N$ individuals who each enters unemployment at time $t=1$. The observation continues until time $t_{i}$, at which point either an event occurs or the observation is censored. Suppose $T_{i}$ is a discrete random variable giving the uncensored time of event occurrence. The conditional hazard function $h\left(t, x_{i}\right)$ for person $i$ given covariates $x_{i}$ is given by

$$
h\left(t, x_{i}\right)=\operatorname{Pr}\left(T_{i}=t \mid T_{i} \geq t, x_{i}\right) \text { for } t=1,2,3, \ldots
$$

The exit rate to employment is specified as follows

$$
\operatorname{Pr}\left(T_{i}=t \mid T_{i} \geq t, x_{i}\right)=F\left(\gamma_{t}+x_{i}^{\prime} \beta_{t}\right)
$$

where $F$ is the $c d f$ (normal or logistic). To introduce state dependence of $h\left(t, x_{i}\right)$, I specify

$$
\gamma_{t}=\gamma_{0}+\gamma_{1}(\log t)
$$

Let $T^{*}$ be the maximum spell observed in the data. Then, such a model amounts to a sequence of $T^{*}$ binary choice models for the surviving populations at each $t$. In particular, for $t=1$ :

$$
\operatorname{Pr}\left(T_{i}=1 \mid T_{i} \geq 1, x_{i}\right)=\operatorname{Pr}\left(y_{1 i}=1 \mid \delta_{1 i}=1, x_{i}\right)=F\left(\gamma_{1}+x_{i}^{\prime} \beta_{1}\right)
$$


where $y_{1 i}=\mathbf{1}\left(T_{i}=1\right)$ and $\delta_{1 i}=\mathbf{1}\left(T_{i} \geq 1\right)$. And so on for $t=2,3$, etc.

The likelihood function for a sample of entrants can be written as:

$$
\log L=\sum_{i=1}^{N} \sum_{t=1}^{T^{*}} \delta_{t i}\left\{y_{t i} \log F\left(\gamma_{t}+x_{i}^{\prime} \beta_{t}\right)+\left(1-y_{t i}\right) \log \left[1-F\left(\gamma_{t}+x_{i}^{\prime} \beta_{t}\right)\right]\right\}
$$

This log likelihood function has the same basic structure of the log likelihood function for a binary regression model in which $y_{t i}$ is the dependent variable and in which the data structure has been reorganized from having one record per spell to having one record for each discrete time period that a unit is at risk of experiencing an event or transition.

The results of the estimation are in Table 7 and 8. I present estimation results based on $F$ having a logistic distribution in Model (1) and (2). In Model (3), I present estimation results based on a normal distribution for $F$. Moreover, in Model (4), I present parameters estimated from Model (2) with normal unobserved heterogeneity.

A possible problem with these specifications regards the endogeneity of spouse's wage. We could think that the couples are not randomly matched: the choice of a husband (wife) does depends on his (her) level of earnings and other characteristics, or that the husband's (wife's) earnings insure the unemployed spouse and affects her (his) reservation wage. In this case, the previous estimates upward bias the coefficient on the spouse's earnings.

To address this issue, I consider a set of instrumental variables that affect spouse's hourly earnings but are not correlated with her (his) spouse variation in possibility to exit unemployment, that is the industrial sector in which the spouse works. Moreover, the husband's (wife's) industrial sector should not be affected by unobserved information about his wife's (her husband's) job finding prospects.

To support the choice of this instrumental variable, I refer to Dickens and Katz (1987a) and Saunders and Marsden (1981). They provide evidence of large differences in wages across industries for seemingly similar jobs both in the US and in Europe.

From a methodological point of view, as Kuhn and Skuterud (2002) point out, there is no widely-used technique for estimating a duration model with an endogenous variable. Here, I use a probit specification to model the correlation between the error term and unobserved characteristics that induce unemployed husbands or wives to look for job. To incorporate endogeneity in the model, I rewrite (2) as follows:

$$
\log \left[\frac{h\left(t, x_{i}\right)}{1-h\left(t, x_{i}\right)}\right]=\gamma_{t}+x_{i}^{\prime} \beta_{t}+w_{i}^{\prime} \alpha_{t}+u_{i}
$$


where $w_{i}$ (previously included in $x_{i}$ ) is the hourly earning of agent's $i$ spouse, with coefficient $\alpha_{t}$, and $u_{i}$ is the error term. Moreover, $w_{i}$ is defined as follows:

$$
w_{i}=z_{i}^{\prime} \lambda_{t}+v_{i}
$$

where $z_{i}$ is a vector of exogenous, non-time varying covariates $x_{i}$, plus an instrumental variable excluded from $x_{i}$. The error term $\left(u_{i}, v_{i}\right)$ follows a bivariate normal distribution, which implies that also the conditional distribution of $u$ given $v$ is normal as follows:

$$
u \mid v, z \sim N\left(\rho v, 1-\rho^{2}\right)
$$

Hence

$$
\begin{aligned}
\operatorname{Pr}\left(T_{i}=t \mid T_{i} \geq t, x_{i}, z_{i}\right) & =\operatorname{Pr}\left(\gamma_{t}+x_{i}^{\prime} \beta_{t}+w_{i}^{\prime} \alpha_{t}+u_{i} \geq 0 \mid v_{i}, z_{i}\right) \\
& =\Phi\left(\frac{\gamma_{t}+x_{i}^{\prime} \beta_{t}+w_{i}^{\prime} \alpha_{t}+\rho v_{i}}{\sqrt{1-\rho^{2}}}\right)
\end{aligned}
$$

The log likelihood function can be written as

$$
\begin{aligned}
\log L & =\sum_{i=1}^{N} \sum_{t=1}^{T^{*}} \delta_{t i}\left\{y_{t i} \log \Phi\left(\frac{\gamma_{t}+x_{i}^{\prime} \beta_{t}+w_{i}^{\prime} \alpha_{t}+\rho v_{i}}{\sqrt{1-\rho^{2}}}\right)\right. \\
& \left.+\left(1-y_{t i}\right) \log \left[1-\Phi\left(\frac{\gamma_{t}+x_{i}^{\prime} \beta_{t}+w_{i}^{\prime} \alpha_{t}+\rho v_{i}}{\sqrt{1-\rho^{2}}}\right)\right]\right\} \\
& +\sum_{i=1}^{N}\left(-\frac{1}{2} \log \sigma_{v_{i}}^{2}-\frac{1}{2} v_{i}^{2}\right)
\end{aligned}
$$

Under exogeneity $(\rho=0)$, this log likelihood function would be the sum of a probit and an ordinary least square log likelihood function.

\section{Results and Discussion}

The results presented in this section focus on married individuals. Only in Table 6, I present the marginal effects of the estimation of Model (4) applied to all individuals, i.e. of any marital status, of age older than 14 and younger than 60. It shows that married men have a significant higher probability of leaving unemployment than

unmarried men. On the contrary, married women have a significant lower probability 
of leaving unemployment than unmarried women.

Non-parametric Kaplan-Meier estimates of the survival functions for married men and women are plotted in Figure 1. As expected, the probability of remaining unemployed is higher for women than for men.

In Figure 2, I report estimates of the Kaplan-Meier survival functions by wage of the spouse. In particular, in the top panel, left figure, we can see the survival function for men whose wives' wage belongs to the bottom $1 \%$ of the distribution. On the right figure, we can see the survival function for men whose wives' wage belongs to the top $1 \%$ of the distribution. On the bottom panel, the same functions are plotted for women, depending on their husbands' wage.

Focusing on the left figures, we can observe that the probability of surviving in the risk pool (i.e. to remain unemployed) is similar for men and women when the spouse's wage is low. Moving to the right figures, we see that it is higher for women with high wage husbands than for husbands with high wage wives. Hence, a first look at the data shows evidence of the asymmetric behavior of unemployed married men and women towards their spouses' labor earnings.

Results from maximizing the likelihood in equation 5 are presented in Table 7 for men and in Table 8 for women. ${ }^{7}$ The coefficients represent the effect of the corresponding variables on the probability that a given individual enter employment during the time period considered. ${ }^{8}$ Note that the sample of men and women are not the opposite sides of an accounting relationship. The spouses of the men in the sample are not necessarily in the sample of the women, and vice versa. The marginal effects are in Table 10 ,

In comparing Table 7 and Table 8, the first result to point out is that the coefficients on the logarithm of spouses' wage are significant and of different signs. In particular, a 100\% increase in wife's hourly earnings increases the monthly probability of leaving unemployment by about 52 percentage points (from the most complete Model (4), Table 10p. For women, a 100\% increase in husband's hourly earnings decreases the monthly probability of leaving unemployment by about 32 percentage points. The baseline monthly hazards for men and women are plotted in Figure 8 . The baseline hazards are scaled to the characteristics of a "average" individual, as in the summary statistics in Tables 3 and 4 . The main feature of these plots is that the baseline hazard in the sample of women lies entirely below that of the men.

Now, consider the effect of the rest of the variables included in the analysis. The

\footnotetext{
${ }^{7}$ The results are robust to the estimation of the pooled sample of married men and women. The coefficients and the marginal effects are in Table 11 and Table 12 , respectively.

${ }^{8} \mathrm{~A}$ positive coefficient resulting from the estimations, indicates that the variable in question increases the hazard rate, i.e. that it decreases expected unemployment duration.
} 
estimated coefficient on dummy for inflow after employment indicates that individuals who entered unemployment or inactivity after being employed have significantly higher chances of leaving unemployment. As shown by most of the existing literature, the registration to the ANPE (or receiving the unemployment benefit) decreases the probability of exiting unemployment. The local unemployment rate is not found to be significant (in all of the specifications for men, and in most of the specifications for women).

The demographic explanatory variables in the model have the expected signs and are mostly statistically significant. In both tables, age and the presence of children decrease the chances of leaving unemployment.

Figure 3 and 4 plot the predicted probabilities from the estimation of Model (2). In Figure 3, the probabilities are computed for three age groups of individuals ${ }^{9}$, and the rest of the regressors are taken at their mean values. In both of the panels of this figure, younger agents have a higher probability of finding a job, regardless of the spouse's earnings. But, in the right panel, the probability of finding a job is an increasing function of the wife's earnings, regardless of the age. In the left panel, the probability of finding a job is a decreasing function of the husband's earnings, regardless of the age. ${ }^{10}$

Figure 4 plots the effect of the presence (or absence) of children younger than three years old on the probability of leaving the risk pool of unemployed. The feature of this figure is that the probability of leaving unemployment for men depends only slightly on the presence of children (from the slight change in intercept). For women the presence of children strongly negatively affects the chances of leaving unemployment.

I continue the analysis of the effects of the presence (or absence) of children in Figures 5 and 6. They plot the predicted probabilities computed from the estimation of Model (4) for the sample of married men (women) without and with children (left and right panel). Figure 5 shows that, once we consider the two samples separately, the effect of having children does not only change the intercept of the estimated function, but also the slope. In particular, regardless of the age, men without children react differently to the earnings of wives than men with children. One possible explanation could be related to the reallocation of time during unemployment, as studied

\footnotetext{
${ }^{9}$ Note that, the age of respondent could be interpreted as a proxy for the length of the marriage.

${ }^{10}$ The same asymmetric relationship between probability to employment and earnings is shown in Figure 7. In these figures, I distinguish between individuals registered to the national agency for the employment (and hence, receiving unemployment benefit), and those who are not registered (and hence, not receiving unemployment benefits). Moreover, the figures confirm the fact showed in previous literature that receiving unemployment benefit decreases the chances of exiting unemployment for both men and women. The difference is particularly noticeable for men.
} 
in Solaz (2005). Men with young children exit slower unemployment as wive's earnings increase because they allocate time to child care rather than job search and they use wive's income as buffer. Hence, conditional on having children, wive's earnings play the standard role of buffer against income shock (due to unemployment). On the contrary, childless men's self-esteem of being supported (positively) affects the effort they exert in finding a job.

In Table 9, I present results of an alternative specification to corroborate a causal effect interpretation of the main results. I instrument for hourly wage of the spouse using a set of dummies for the industrial sector in which the spouse is employed (or she/he had been employed before the last unemployment spell started). Dickens and Katz (1987b) and Krueger and Summers (1987) present evidence of the correlation between wages and industrial sectors. Moreover, the variation in this measure essentially derives from the same source as the measure of hourly earnings, that is changes in demand for workers in a given industry. Hence, we would expect similar results based on the two measures. The coefficients are presented in Table 9, and the marginal effects are in the last column of Table 10.

Results confirm a significant positive elasticity of 0.38 of unemployment duration of married men to their wives' hourly earnings, and a significant negative elasticity of -0.26 of unemployment duration of married women to their husbands' hourly earnings.

\section{Conclusion}

In this paper, I provide empirical evidence of the existing asymmetry in the probability of leaving unemployment of French married men and women. I show that the results are robust when controlling for unobserved heterogeneity and endogeneity of the explanatory variables.

Understanding the origin of this gender difference may be interesting to design unemployment insurance schemes that take into account the labor market situation of the spouse, other than of demographic characteristics.

Most of the literature on household economics studies the intra-household behavior of husbands and wives, and the different incentives schemes that lead them to participate or not in the labor market. A vast literature is dedicated to the consequences of fertility choices, or exogenous differences in the labor market, on the labor market choices of married women.

Not too much space has been dedicated so far to develop models where labor market frictions generate asymmetric reactions of married men and women, as the ones we observe empirically. 


\section{A Figures}

Figure 1: Kaplan-Meier Survival Estimates

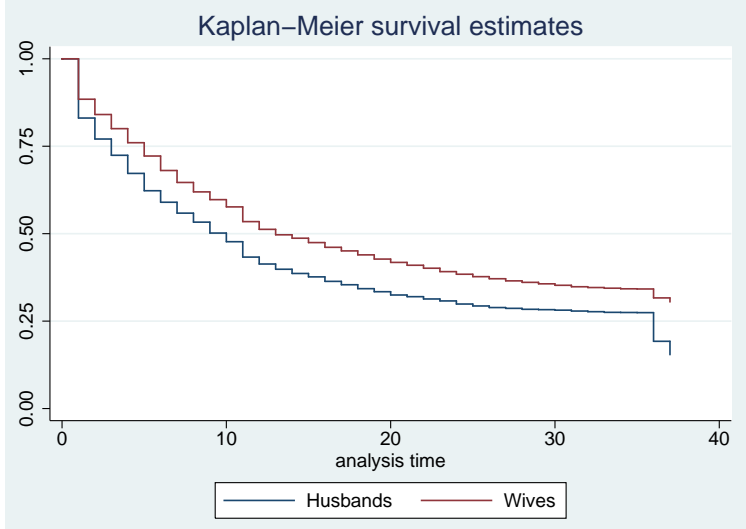

Figure 2: Kaplan-Meier Survival Estimates by Wage of Spouse
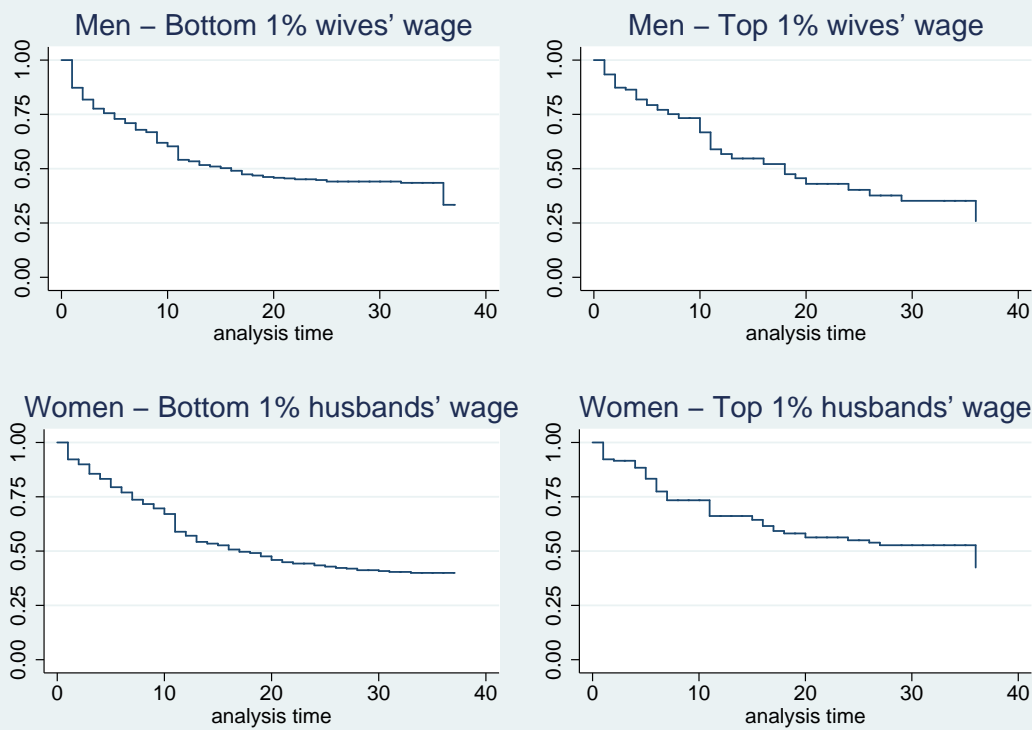
Figure 3: Estimation Results - Women and Men
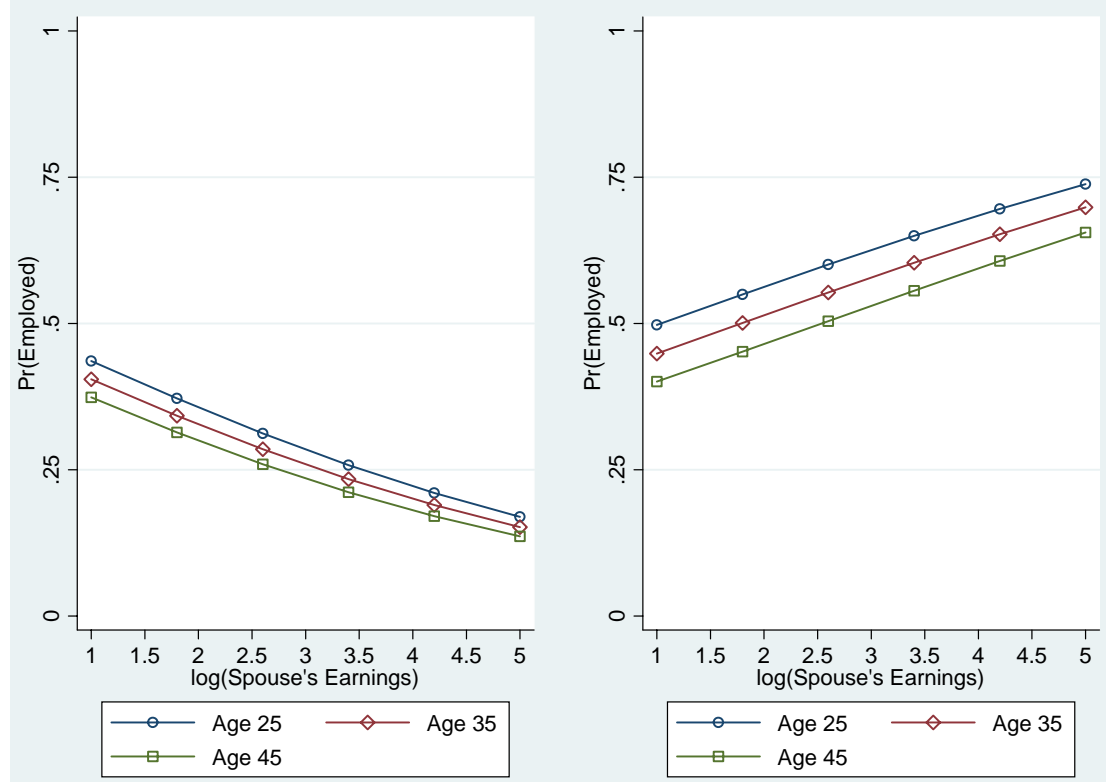

Figure 4: Estimation Results - Women and Men
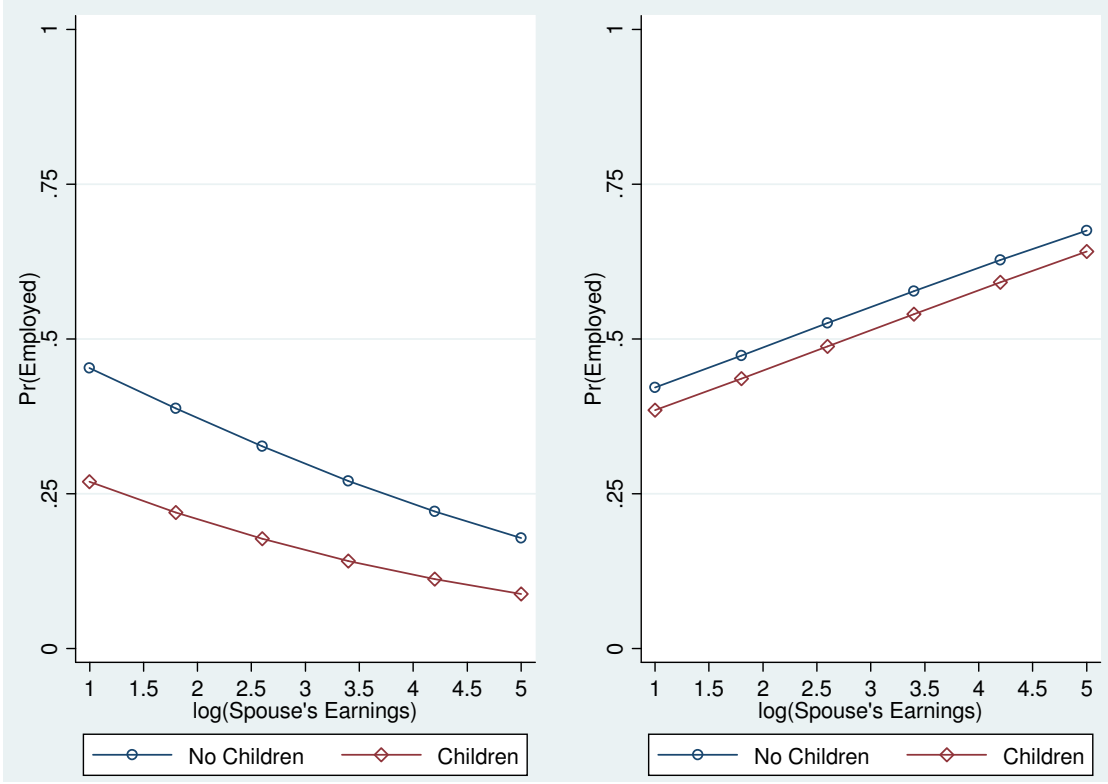
Figure 5: Men Without and With Children Less than 3 yrs old
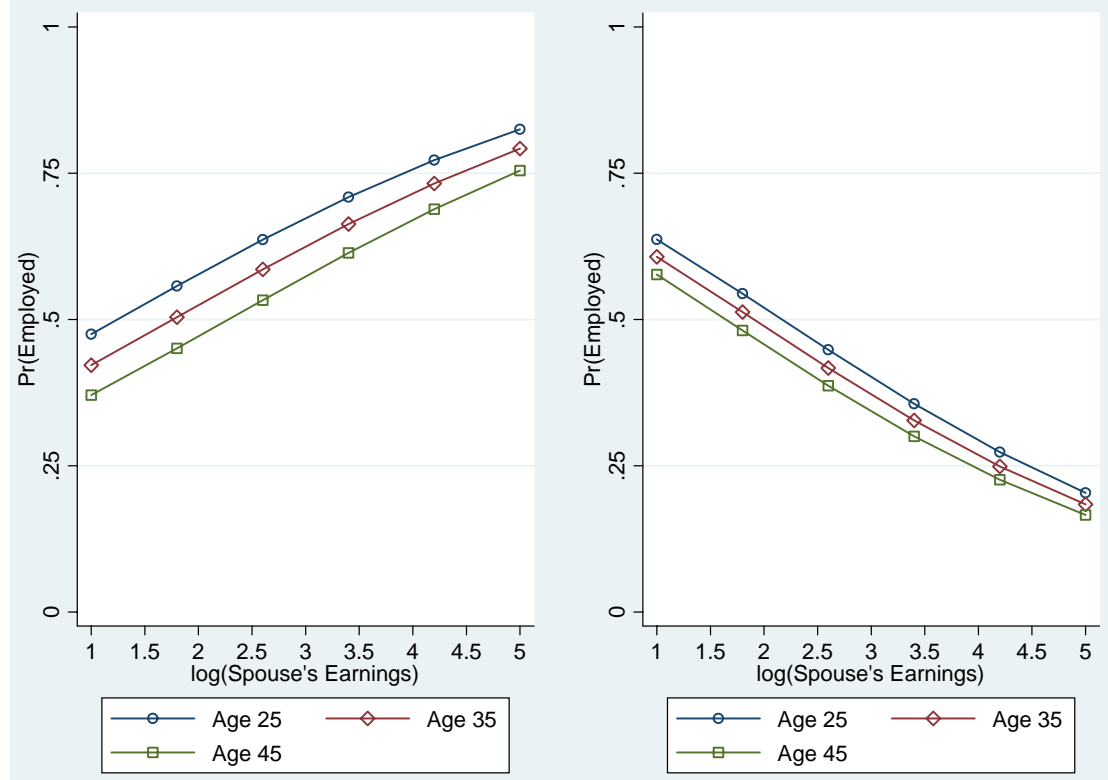

Figure 6: Women Without and With Children Less than 3 yrs old
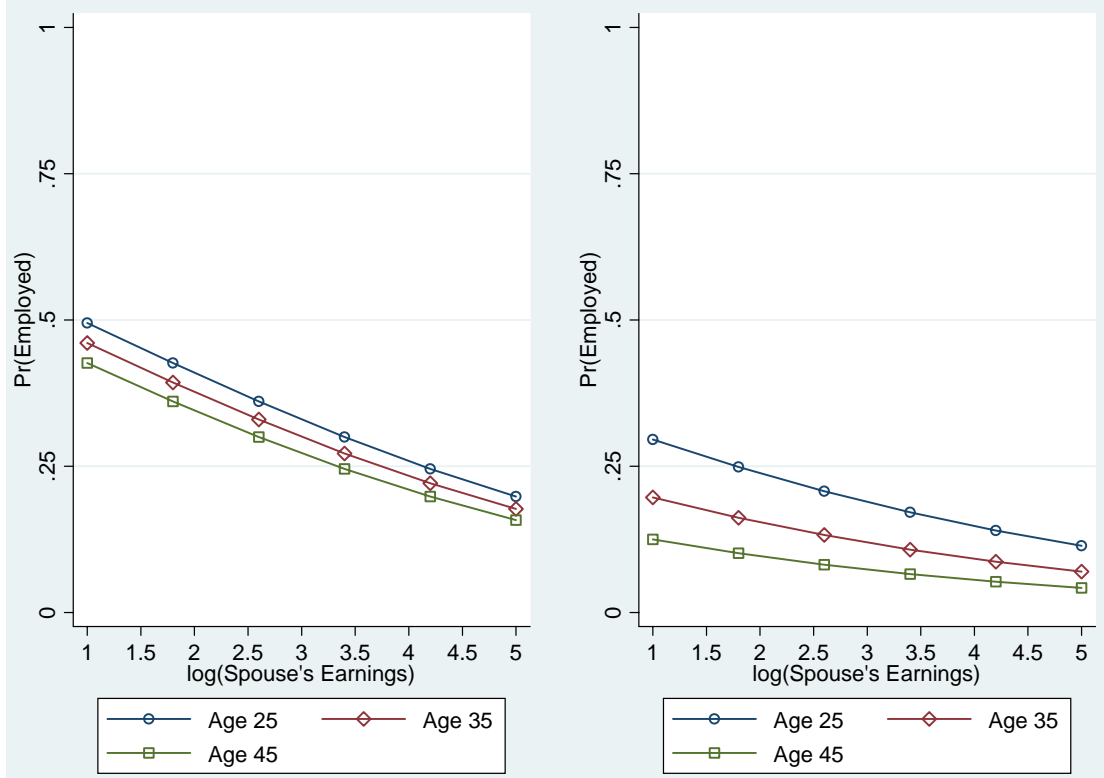
Figure 7: Estimation Results - Women and Men
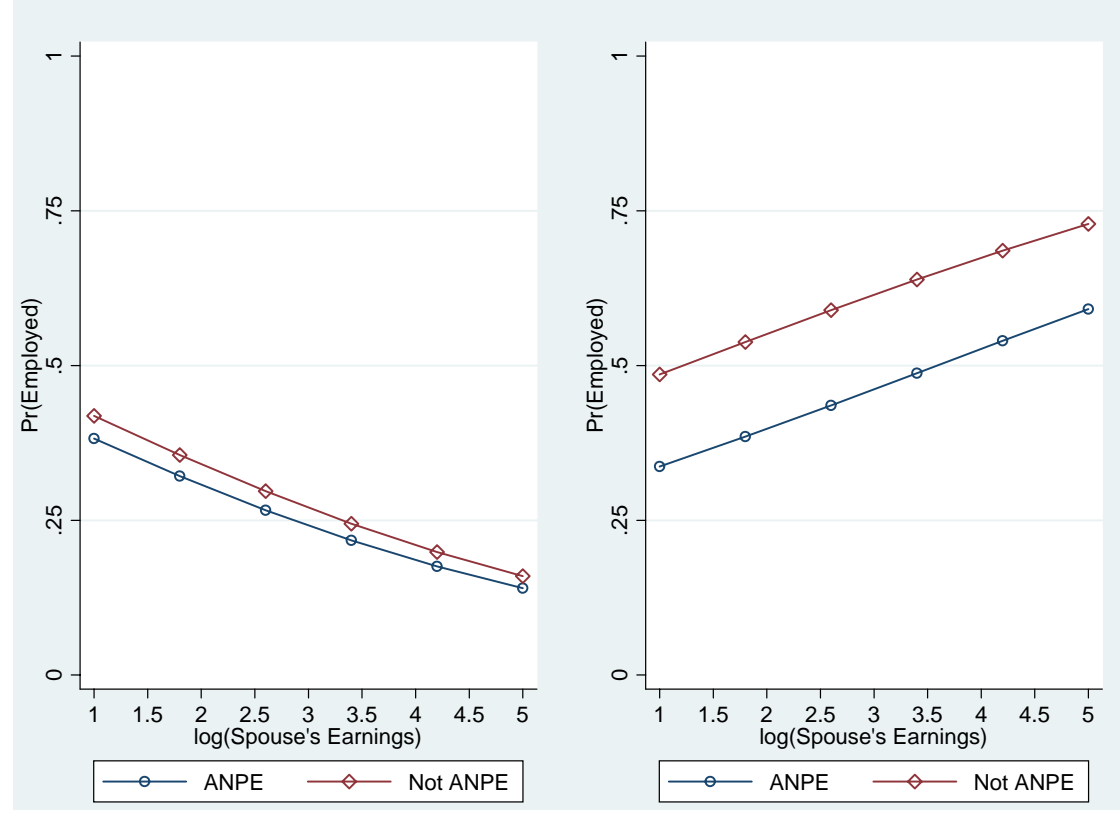

Figure 8: Baseline Hazard - Women and Men
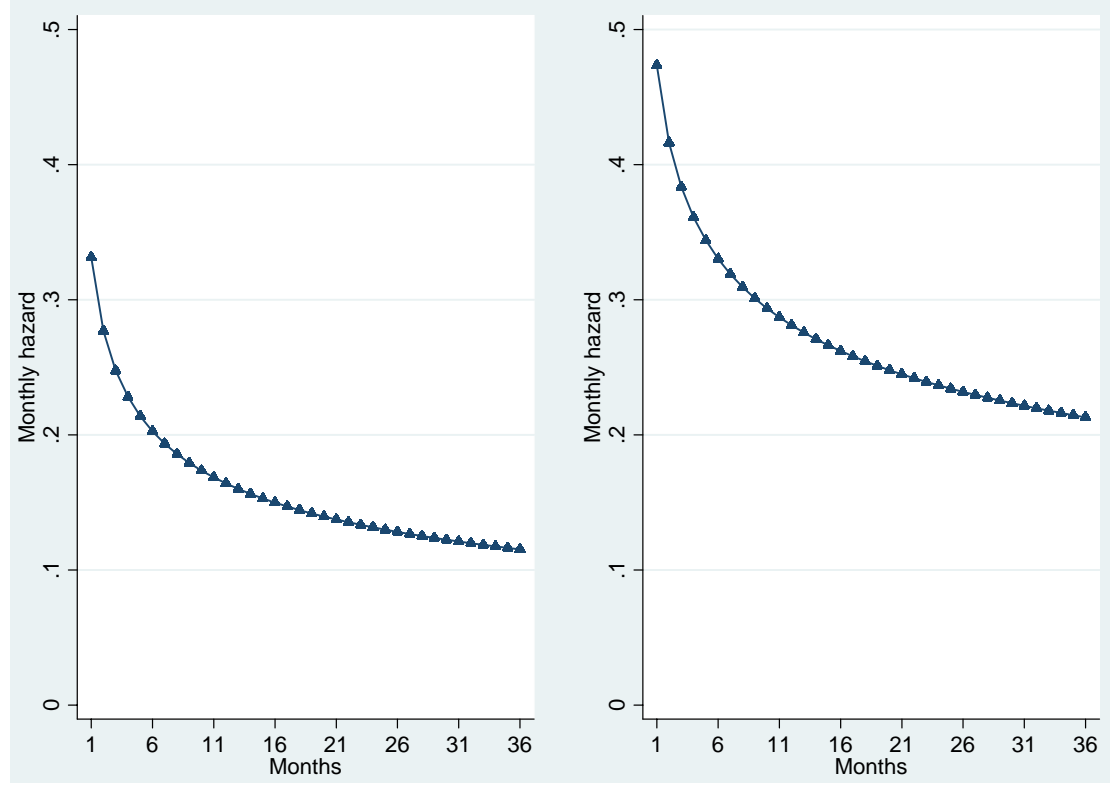


\section{B Tables}

Table 1: Survey Years and No. of Observations After Restrictions

\begin{tabular}{ccccc}
\hline Survey Year & No. Initial Obs. & No. Final Obs. & No. Husbands & No. Wives \\
\hline 1991 & 137,298 & 823 & 359 & 769 \\
1992 & 141,053 & 817 & 278 & 539 \\
1993 & 146,803 & 746 & 293 & 453 \\
1994 & 151,590 & 1,026 & 332 & 694 \\
1995 & 151,146 & 844 & 330 & 514 \\
1996 & 150,365 & 963 & 368 & 595 \\
1997 & 148,891 & 1,214 & 389 & 825 \\
1998 & 149,132 & 731 & 251 & 480 \\
1999 & 182,155 & 697 & 237 & 460 \\
2000 & 182,066 & 1,197 & 379 & 818 \\
2001 & 178,143 & 708 & 204 & 504 \\
2002 & 175,939 & 757 & 240 & 517 \\
\hline
\end{tabular}


Table 2: Transition from Unemployment to Employment

\begin{tabular}{lccccc}
\hline HUSBANDS & Total & Mean & Min & Median & Max \\
\hline no. of subjects & 2022 & & & & \\
no. of records & 3660 & 1.81 & 1 & 2 & 8 \\
(first) entry time & & 0 & 0 & 0 & 0 \\
(final) exit rate & & 20.15 & 1 & 21 & 37 \\
subjects with gap & 1220 & & & & \\
time on gap if gap & 5496 & 3.53 & 1 & 1 & 33 \\
time at risk & 35241 & 17.43 & 1 & 12 & 36 \\
total failures & 2091 & 1.03 & 0 & 1 & 7 \\
\hline WIVES & & & & & \\
\hline no. of subjects & 3616 & & & & \\
no. of records & 7168 & 1.98 & 1 & 2 & 11 \\
(first) entry time & & 0 & 0 & 0 & 0 \\
(final) exit rate & & 23.50 & 1 & 27 & 37 \\
subjects with gap & 2484 & & & & \\
time on gap if gap & 10204 & 2.97 & 1 & 1 & 26 \\
time at risk & 74775 & 20.68 & 1 & 20 & 36 \\
total failures & 3175 & 0.88 & 0 & 1 & 9 \\
\hline
\end{tabular}


Table 3: Summary Statistics - Husbands - Panel 1991 to 2002

\begin{tabular}{|c|c|c|c|c|c|}
\hline Variable & Mean & (Std. Dev.) & Min. & Max. & $\mathbf{N}$ \\
\hline Wives' hourly wage & 6.76 & $(4.42)$ & 4.98 & 98.03 & 3660 \\
\hline Age & 40.60 & $(10.66)$ & 19 & 57 & 3660 \\
\hline Years of education & 10.43 & $(3.32)$ & 5 & 17 & 3289 \\
\hline \multicolumn{6}{|l|}{ Number of children: } \\
\hline less than 3 yrs old & 0.12 & $(0.34)$ & 0 & 2 & 3660 \\
\hline less than 6 yrs old & 0.27 & $(0.54)$ & 0 & 3 & 3660 \\
\hline less than 18 yrs old & 0.84 & $(1.01)$ & 0 & 6 & 3660 \\
\hline \multicolumn{6}{|l|}{ Region of residence: } \\
\hline North & 0.48 & $(0.50)$ & 0 & 1 & 3660 \\
\hline Center & 0.35 & $(0.48)$ & 0 & 1 & 3660 \\
\hline South & 0.17 & $(0.38)$ & 0 & 1 & 3660 \\
\hline French nationality & 0.92 & $(0.28)$ & 0 & 1 & 3660 \\
\hline Non-French nationality & 0.08 & $(0.28)$ & 0 & 1 & 3660 \\
\hline Spouse never unemployed & 0.51 & $(0.5)$ & 0 & 1 & 3660 \\
\hline \multicolumn{6}{|l|}{ Spouse unemployed: } \\
\hline less than 6 months & 0.25 & $(0.43)$ & 0 & 1 & 3660 \\
\hline between 7 and 12 months & 0.07 & $(0.25)$ & 0 & 1 & 3660 \\
\hline between 13 and 18 months & 0.08 & $(0.28)$ & 0 & 1 & 3660 \\
\hline between 19 and 24 months & 0.05 & $(0.21)$ & 0 & 1 & 3660 \\
\hline 25 and 30 months & 0.04 & $(0.2)$ & 0 & 1 & 3660 \\
\hline more than 31 months & 0.005 & $(0.07)$ & 0 & 1 & 3660 \\
\hline Owner of real estate & 0.53 & $(0.50)$ & 0 & 1 & 3660 \\
\hline Renter & 0.46 & $(0.50)$ & 0 & 1 & 3660 \\
\hline Upper manager & 0.00 & $(0.06)$ & 0 & 1 & 3497 \\
\hline Lower manager & 0.10 & $(0.30)$ & 0 & 1 & 3497 \\
\hline Salaried worker & 0.18 & $(0.38)$ & 0 & 1 & 3497 \\
\hline Skilled worker & 0.72 & $(0.45)$ & 0 & 1 & 3497 \\
\hline Regional unemployment rate & 9.42 & $(2.03)$ & 5.03 & 15.32 & 3660 \\
\hline Registered to the ANPE & 0.52 & $(0.5)$ & 0 & 1 & 3660 \\
\hline Inflow after permanent employment & 0.36 & $(0.48)$ & 0 & 1 & 3660 \\
\hline Inflow after temporary employment & 0.21 & $(0.41)$ & 0 & 1 & 3660 \\
\hline Inflow after being a student or in the military & 0.00 & $(0.05)$ & 0 & 1 & 3660 \\
\hline Inflow after any other non participation state & 0.43 & $(0.49)$ & 0 & 1 & 3660 \\
\hline $1991-1993$ & & & & & 930 \\
\hline 1994-1996 & & & & & 1030 \\
\hline 1997-1999 & & & & & 877 \\
\hline 2000-2002 & & & & & 823 \\
\hline
\end{tabular}


Table 4: Summary Statistics - Wives - Panel 1991 to 2002

\begin{tabular}{lccccc}
\hline \multicolumn{1}{c}{ Variable } & Mean & (Std. Dev.) & Min. & Max. & N \\
\hline Husbands' hourly wage & 7.24 & $(3.77)$ & 4.98 & 128.41 & 7168 \\
Age & 34.92 & $(9.15)$ & 18 & 57 & 7168 \\
Years of education & 10.71 & $(3.18)$ & 5 & 17 & 6523 \\
Number of children: & & & & & \\
less than 3 yrs old & 0.24 & $(0.45)$ & 0 & 3 & 7168 \\
less than 6 yrs old & 0.47 & $(0.69)$ & 0 & 4 & 7168 \\
less than 18 yrs old & 1.17 & $(1.09)$ & 0 & 9 & 7168 \\
Region of residence: & & & & & \\
North & 0.46 & $(0.5)$ & 0 & 1 & 7168 \\
Center & 0.37 & $(0.48)$ & 0 & 1 & 7168 \\
South & 0.16 & $(0.37)$ & 0 & 1 & 7168 \\
French nationality & 0.95 & $(0.22)$ & 0 & 1 & 7168 \\
Non-French nationality & 0.05 & $(0.22)$ & 0 & 1 & 7168 \\
Spouse never unemployed & 0.61 & $(0.49)$ & 0 & 1 & 7168 \\
Spouse unemployed: & & & & & \\
for less than 6 months & 0.28 & $(0.45)$ & 0 & 1 & 7168 \\
between 7 and 12 months & 0.05 & $(0.21)$ & 0 & 1 & 7168 \\
between 13 and 18 months & 0.04 & $(0.21)$ & 0 & 1 & 7168 \\
between 19 and 24 months & 0.02 & $(0.12)$ & 0 & 1 & 7168 \\
between 25 and 30 months & 0.01 & $(0.09)$ & 0 & 1 & 7168 \\
more than 31 months & 0.00 & $(0.03)$ & 0 & 1 & 7168 \\
Owner of real estate & 0.49 & $(0.50)$ & 0 & 1 & 7168 \\
Renter & 0.51 & $(0.50)$ & 0 & 1 & 7168 \\
Upper manager & 0.00 & $(0.05)$ & 0 & 1 & 7076 \\
Lower manager & 0.04 & $(0.19)$ & 0 & 1 & 7076 \\
Salaried worker & 0.11 & $(0.31)$ & 0 & 1 & 7076 \\
Skilled worker & 0.85 & $(0.35)$ & 0 & 1 & 7076 \\
Regional unemployment rate & 9.37 & $(2.02)$ & 5.03 & 15.32 & 7176 \\
Registered to the ANPE & 0.48 & $(0.5)$ & 0 & 1 & 7176 \\
Inflow after permanent employment & 0.26 & $(0.44)$ & 0 & 1 & 7168 \\
Inflow after temporary employment & 0.24 & $(0.43)$ & 0 & 1 & 7168 \\
Inflow after being a student or in the military & 0.00 & $(0.05)$ & 0 & 1 & 7168 \\
Inflow after any other non participation state & 0.50 & $(0.50)$ & 0 & 1 & 7168 \\
1991-1993 & & & & & 1761 \\
1994-1996 & & & & & 1803 \\
1997-1999 & & & & & 1765 \\
2000-2002 & & & & & \\
\hline & & & 0.3839 \\
\hline
\end{tabular}


Table 5: Salaire minimum interprofessionnel de croissance (SMIC)

\begin{tabular}{cc}
\hline Year & Amount in euros of hourly gross SMIC \\
\hline 1991 & 4.98 \\
1992 & 5.19 \\
1993 & 5.31 \\
1994 & 5.42 \\
1995 & 5.64 \\
1996 & 5.78 \\
1997 & 6.01 \\
1998 & 6.13 \\
1999 & 6.21 \\
2000 & 6.41 \\
2001 & 6.67 \\
2002 & 6.83 \\
\hline
\end{tabular}

Source: INSEE

Table 6: Marginal Effects - Marital Status $(1=$ Married $)$

\begin{tabular}{lc}
\hline & $(4)$ \\
\hline Men & $0.271^{* * *}$ \\
Women & $(0.059)$ \\
& $-0.257^{* * *}$ \\
Controls & $(0.072)$ \\
\hline
\end{tabular}

Robust standard errors in parentheses 
Table 7: Husbands, Coefficients - The dependent variable is Employment

\begin{tabular}{|c|c|c|c|c|}
\hline VARIABLES & $\begin{array}{c}(1) \\
\text { Logit }\end{array}$ & $\begin{array}{c}(2) \\
\text { Logit }\end{array}$ & $\begin{array}{c}(3) \\
\text { Probit }\end{array}$ & $\begin{array}{c}(4) \\
\text { Logit u.h. }\end{array}$ \\
\hline Wives' $\log$ (hourly wage) & $\begin{array}{c}0.097^{* * *} \\
(0.029)\end{array}$ & $\begin{array}{c}0.261^{* *} \\
(0.039)\end{array}$ & $\begin{array}{c}0.155^{* * *} \\
(0.023)\end{array}$ & $\begin{array}{c}0.518^{* * *} \\
(0.163)\end{array}$ \\
\hline Age & & $\begin{array}{c}-0.019^{* * *} \\
(0.001)\end{array}$ & $\begin{array}{c}-0.012^{* * *} \\
(0.006)\end{array}$ & $\begin{array}{c}-0.044^{* * *} \\
(0.005)\end{array}$ \\
\hline Years of education & & $\begin{array}{c}0.018^{* * *} \\
(0.003)\end{array}$ & $\begin{array}{c}0.010^{* * *} \\
(0.002)\end{array}$ & $\begin{array}{c}0.079 * * * \\
(0.014)\end{array}$ \\
\hline No. of children less than 3 yrs old & & $\begin{array}{c}-0.138^{* * *} \\
(0.029)\end{array}$ & $\begin{array}{c}-0.080^{* * *} \\
(0.016)\end{array}$ & $\begin{array}{c}-0.943^{* * *} \\
(0.111)\end{array}$ \\
\hline Region of residence: North & & $\begin{array}{c}0.027 \\
(0.025)\end{array}$ & $\begin{array}{c}0.012 \\
(0.015)\end{array}$ & $\begin{array}{l}-0.008 \\
(0.139)\end{array}$ \\
\hline Region of residence: Center & & $\begin{array}{c}0.247^{* * *} \\
(0.028)\end{array}$ & $\begin{array}{c}0.143^{* * *} \\
(0.017)\end{array}$ & $\begin{array}{c}0.174 \\
(0.162)\end{array}$ \\
\hline French nationality & & $\begin{array}{c}0.089^{* * *} \\
(0.031)\end{array}$ & $\begin{array}{c}0.058^{* * *} \\
(0.018)\end{array}$ & $\begin{array}{l}-0.091 \\
(0.165)\end{array}$ \\
\hline Owner of real estate & & $\begin{array}{c}0.331^{* * *} \\
(0.019)\end{array}$ & $\begin{array}{c}0.199^{* * *} \\
(0.012)\end{array}$ & $\begin{array}{c}0.449 * * * \\
(0.099)\end{array}$ \\
\hline Lower manager & & $\begin{array}{c}-0.545^{* * *} \\
(0.159)\end{array}$ & $\begin{array}{c}-0.335^{* * *} \\
(0.090)\end{array}$ & $\begin{array}{c}-3.403^{* * *} \\
(0.456)\end{array}$ \\
\hline Salaried worker & & $\begin{array}{c}-0.559 * * * \\
(0.031)\end{array}$ & $\begin{array}{c}-0.339^{* * *} \\
(0.018)\end{array}$ & $\begin{array}{c}-1.536^{* * *} \\
(0.124)\end{array}$ \\
\hline Skilled worker & & $\begin{array}{c}-0.318^{* * *} \\
(0.023)\end{array}$ & $\begin{array}{c}-0.189^{* * *} \\
(0.013)\end{array}$ & $\begin{array}{c}-2.114^{* * *} \\
(0.086)\end{array}$ \\
\hline Regional unemployment rate & & $\begin{array}{c}0.003 \\
(0.005)\end{array}$ & $\begin{array}{c}0.001 \\
(0.003)\end{array}$ & $\begin{array}{l}-0.006 \\
(0.029)\end{array}$ \\
\hline Registered to the ANPE & & $\begin{array}{c}-0.620^{* * *} \\
(0.019)\end{array}$ & $\begin{array}{c}-0.366^{* * *} \\
(0.011)\end{array}$ & $\begin{array}{c}-0.467^{* * *} \\
(0.063)\end{array}$ \\
\hline Inflow after employment & & $\begin{array}{c}1.250^{* * *} \\
(0.020)\end{array}$ & $\begin{array}{c}0.752^{* * *} \\
(0.012)\end{array}$ & $\begin{array}{c}1.656^{* * *} \\
(0.049)\end{array}$ \\
\hline Spouse's unemployment duration & $\mathrm{NO}$ & YES & YES & YES \\
\hline Year fixed effects & YES & YES & YES & YES \\
\hline Panel fixed effects & YES & YES & YES & YES \\
\hline Log likelihood & -54939.753 & -45308.072 & -45271.303 & -14262.094 \\
\hline
\end{tabular}


Table 8: Wives, Coefficients - The dependent variable is Employment

\begin{tabular}{|c|c|c|c|c|}
\hline VARIABLES & $\begin{array}{c}(1) \\
\text { Logit }\end{array}$ & $\begin{array}{c}(2) \\
\text { Logit }\end{array}$ & $\begin{array}{c}(3) \\
\text { Probit }\end{array}$ & $\begin{array}{c}\text { (4) } \\
\text { Logit u.h. }\end{array}$ \\
\hline Husbands' $\log$ (hourly wage) & $\begin{array}{c}-0.056^{* * *} \\
(0.018)\end{array}$ & $\begin{array}{c}-0.333^{* * *} \\
(0.024)\end{array}$ & $\begin{array}{c}-0.199^{* * *} \\
(0.014)\end{array}$ & $\begin{array}{c}-0.317^{*} \\
(0.181)\end{array}$ \\
\hline Age & & $\begin{array}{c}-0.013^{* * *} \\
(0.001)\end{array}$ & $\begin{array}{c}-0.008^{* * *} \\
(0.000)\end{array}$ & $\begin{array}{c}-0.018^{* * *} \\
(0.006)\end{array}$ \\
\hline Years of education & & $\begin{array}{c}0.040 * * * \\
(0.002)\end{array}$ & $\begin{array}{c}0.024^{* * *} \\
(0.001)\end{array}$ & $\begin{array}{c}0.043^{* * *} \\
(0.011)\end{array}$ \\
\hline No. of children less than 3 yrs old & & $\begin{array}{c}-0.732^{* * *} \\
(0.016)\end{array}$ & $\begin{array}{c}-0.423^{* * *} \\
(0.009)\end{array}$ & $\begin{array}{c}-0.814^{* * *} \\
(0.054)\end{array}$ \\
\hline Region of residence: North & & $\begin{array}{c}0.026 \\
(0.018)\end{array}$ & $\begin{array}{c}0.015 \\
(0.011)\end{array}$ & $\begin{array}{c}0.284^{* *} \\
(0.135)\end{array}$ \\
\hline Region of residence: Center & & $\begin{array}{c}0.255^{* * *} \\
(0.020)\end{array}$ & $\begin{array}{c}0.151^{* * *} \\
(0.012)\end{array}$ & $\begin{array}{c}0.564^{* * *} \\
(0.146)\end{array}$ \\
\hline French nationality & & $\begin{array}{c}0.452^{* * *} \\
(0.030)\end{array}$ & $\begin{array}{c}0.257^{* * *} \\
(0.017)\end{array}$ & $\begin{array}{c}0.150 \\
(0.158)\end{array}$ \\
\hline Owner of real estate & & $\begin{array}{c}0.226^{* * *} \\
(0.013)\end{array}$ & $\begin{array}{c}0.136^{* * *} \\
(0.007)\end{array}$ & $\begin{array}{c}0.238^{* *} \\
(0.093)\end{array}$ \\
\hline Lower manager & & $\begin{array}{c}-0.275^{* *} \\
(0.117)\end{array}$ & $\begin{array}{c}-0.182^{* * *} \\
(0.070)\end{array}$ & $\begin{array}{l}-0.559 \\
(0.967)\end{array}$ \\
\hline Salaried worker & & $\begin{array}{c}0.296^{* * *} \\
(0.034)\end{array}$ & $\begin{array}{c}0.173^{* * *} \\
(0.020)\end{array}$ & $\begin{array}{c}-0.972^{* * *} \\
(0.110)\end{array}$ \\
\hline Skilled worker & & $\begin{array}{c}0.212^{* * *} \\
(0.019)\end{array}$ & $\begin{array}{c}0.126^{* * *} \\
(0.012)\end{array}$ & $\begin{array}{c}-0.886^{* * *} \\
(0.063)\end{array}$ \\
\hline Regional unemployment rate & & $\begin{array}{c}-0.012^{* * *} \\
(0.004)\end{array}$ & $\begin{array}{c}-0.007^{* * *} \\
(0.002)\end{array}$ & $\begin{array}{l}-0.039 \\
(0.027)\end{array}$ \\
\hline Registered to the ANPE & & $\begin{array}{c}-0.153^{* * *} \\
(0.013)\end{array}$ & $\begin{array}{c}-0.081^{* * *} \\
(0.008)\end{array}$ & $\begin{array}{c}-0.166^{* * *} \\
(0.047)\end{array}$ \\
\hline Inflow after employment & & $\begin{array}{c}1.306^{* * *} \\
(0.013)\end{array}$ & $\begin{array}{c}0.787^{* * *} \\
(0.008)\end{array}$ & $\begin{array}{c}1.133^{* * *} \\
(0.033)\end{array}$ \\
\hline Spouse's unemployment duration & $\mathrm{NO}$ & YES & YES & YES \\
\hline Year fixed effects & YES & YES & YES & YES \\
\hline Panel fixed effects & YES & YES & YES & YES \\
\hline Log likelihood & -106404.19 & -86998.436 & -86902.342 & -27365.352 \\
\hline
\end{tabular}


Table 9: Duration Model With Endogeneity Correction

\begin{tabular}{lcc}
\hline & Husbands, Coefficients & Wives, Coefficients \\
\hline Spouses' log hourly wage & $0.378^{* * *}$ & $-0.154^{* * *}$ \\
& $(0.084)$ & $(0.043)$ \\
Controls as in $(2)-(4)$ & YES & YES \\
Rho & -0.055 & -0.030 \\
& $(0.018)$ & $(0.010)$ \\
\hline
\end{tabular}

Robust standard errors in parentheses

Table 10: Marginal Effects

\begin{tabular}{lccccc}
\hline & $(1)$ & $(2)$ & $(3)$ & $(4)$ & IV \\
\hline Wives' $\log$ (hourly wage) & $0.024^{* * *}$ & $0.065^{* * *}$ & $0.062^{* * *}$ & $0.518^{* * *}$ & $0.378^{* * *}$ \\
& $(0.007)$ & $(0.010)$ & $(0.009)$ & $(0.163)$ & $(0.084)$ \\
Husbands' $\log$ (hourly wage) & $-0.013^{* * *}$ & $-0.074^{* * *}$ & $-0.072^{* * *}$ & $-0.317^{*}$ & $-0.154^{* * *}$ \\
& $(0.003)$ & $(0.005)$ & $(0.005)$ & $(0.181)$ & $(0.043)$ \\
Controls & NO & YES & YES & YES & YES \\
\hline
\end{tabular}

Robust standard errors in parentheses 
Table 11: Panel Married Men And Women - Coefficients

\begin{tabular}{lcccc}
\hline & $(1)$ & $(2)$ & $(3)$ & $(4)$ \\
\hline $1=$ Woman & $-0.129^{* *}$ & $0.183^{* *}$ & $0.111^{* *}$ & $0.445^{* * *}$ \\
& $(0.064)$ & $(0.074)$ & $(0.044)$ & $(0.157)$ \\
$(1=\text { Woman })^{*} \log$ (hourly wage) & $-0.229^{* * *}$ & $-0.379^{* * *}$ & $-0.228^{* * *}$ & $-0.840^{* * *}$ \\
& $(0.033)$ & $(0.039)$ & $(0.023)$ & $(0.081)$ \\
$\log ($ hourly wage) & $0.151^{* * *}$ & $0.159^{* * *}$ & $0.095^{* * *}$ & $0.669^{* * *}$ \\
& $(0.028)$ & $(0.034)$ & $(0.021)$ & $(0.060)$ \\
Controls & NO & YES & YES & YES \\
\hline
\end{tabular}

Robust standard errors in parentheses

Table 12: Panel Married Men And Women - Marginal Effects

\begin{tabular}{lcccc}
\hline & $(1)$ & $(2)$ & $(3)$ & $(4)$ \\
\hline $1=$ Woman & $-0.031^{* *}$ & $0.043^{* *}$ & $0.042^{* *}$ & $0.445^{* * *}$ \\
& $(0.015)$ & $(0.017)$ & $(0.017)$ & $(0.157)$ \\
$(1=\text { Woman })^{*} \log$ (hourly wage) & $-0.055^{* * *}$ & $-0.089^{* * *}$ & $-0.087^{* * *}$ & $-0.840^{* * *}$ \\
& $(0.008)$ & $(0.009)$ & $(0.009)$ & $(0.081)$ \\
$\log ($ hourly wage $)$ & $0.036^{* * *}$ & $0.037^{* * *}$ & $0.036^{* * *}$ & $0.669^{* * *}$ \\
& $(0.007)$ & $(0.008)$ & $(0.008)$ & $(0.060)$ \\
Controls & NO & YES & YES & YES \\
\hline
\end{tabular}

Robust standard errors in parentheses 


\section{Variables}

In this Appendix I provide details of the computation of the variables used in the empirical analysis. Each agent is identified by the variables AIRE, IMLOC, NOI, and S (sex).

Log(Spouse's hourly wage): monthly earnings are computed from the variables SALRED and (SALFR + PRIMFR*(1/12)) when SALRED is not available. The amounts are deflated using the consumer price deflator available at the web site of the INSEE ${ }^{11}$. Weekly hours worked are imputed from DUHAB, and replaced by the average weekly hours worked by men and women if DUHAB is not available but the reported wage is positive. In the cases in which the hourly wage is not higher than the minimum legal wage of that year, the hourly wage considered is the latter. See Table 5 for details on the minimum legal hourly wage, or salaire minimum interprofessionnel de croissance (SMIC).

Age: the variable is AG.

Years of education: the variable DIPL1 is recoded to get the average number of years spent in school.

No. of children less than 3 yrs old: the variable is ENF3.

Region of residence: the variable $R G$ is split in three more variables that I named North, Center, and South. The north of France includes the following regions: Picardie, Haute-Normandie, Nord-Pas de Calais, Champagne-Ardennes, Lorraine, Alsace, Ile-de-France, Basse-Normandie. Center includes: Pays de la Loire, Bretagne, Centre, Bourgogne, Franche-Comté, Poitou-Charentes, Limousin, RhôneAlpes, Auvergne. South includes: Languedoc-Roussillon, Provence-Cte d'AzurCorse, Aquitaine, Midi-Pyrénées.

French nationality: the variable is N.

Owner of real estate: the variable is SO.

Occupation: the variable DCSTOT is used to distinguish four type of occupations as described above.

Regional unemployment rate: data available at the INSEE web site ${ }^{12}$.

Registered to the ANPE: the variable is ANPE, and indicates the registration to the "Agence nationale pour l'emploi".

Inflow after permanent employment, temporary employment, school or military: the variable is FI recorded at the month which precedes the unemployment spell.

\footnotetext{
${ }^{11}$ http : //www.insee.fr/fr/themes/conjoncture/historique ${ }_{i}$ pc.asp

${ }^{12}$ http : //www.insee.fr/fr/themes/tableau.asp? reg $_{\mathrm{i}} \mathrm{d}=$ =99ref $\mathrm{f}_{\mathrm{i}} \mathrm{d}=$ CMRSOS03311
} 
Spouse's unemployment duration: After matching the couples, I sum up the number of months where the spouse has declared to be unemployed. I distinguish between several states: never unemployed; unemployed for less than 6 months; unemployed for less than 12 but more than 6; unemployed for less than 18 but more than 12 months; unemployed for less than 24 but more than 18 months; unemployed for less than 30 but more than 24 months; unemployed for more than 30 months.

\section{Acknowledgments}

I thank Andrew Clark, Margherita Comola, Michela Limardi, Julien Prat, participants to the Applied Economics Lunch Seminar at Paris School of Economics, and to the 2010 European Summer Symposium in Labour Economics in Buch am Ammersee for comments and suggestions. I also thank the Centre Maurice Halbwachs (CMH) for making the data available. All errors are mine. 


\section{References}

Arulampalam, W., And M. B. Stewart (1995): "The Determinants of Individual Unemployment Durations in an Era of High Unemployment," The Economic Journal, 105(429), pp. 321-332.

Bloemen, H. G., and E. G. F. Stancanelli (2001): "Individual Wealth, Reservation Wages, and Transitions into Employment," Journal of Labor Economics, 19(2), 400-439.

Bulent, G., F. Guvenen, and G. Violante (2010): "Joint-Search Theory: New Opportunities and New Frictions," Discussion paper.

Burdett, K. (1978): "A Theory of Employee Job Search and Quit Rates," The American Economic Review, 68(1), pp. 212-220.

DAnforth, J. P. (1979): "On the Role of Consumption and Decreasing Absolute Risk Aversion in the Theory of Job Search," in Studies in the Economics of Search, ed. by S. A. Lippman, and J. J. M. (Eds.). New York: North-Holland.

Dickens, W. T., And L. F. Katz (1987a): "Inter-Industry Wage Differences and Theories of Wage Determination," NBER Working Papers 2271, National Bureau of Economic Research, Inc.

(1987b): "Interindustry Wage Differences and Industry Characteristics," Working Paper 2014, National Bureau of Economic Research.

Kiefer, N. M. (1988): "Economic Duration Data and Hazard Functions," Journal of Economic Literature, 26(2), pp. 646-679.

Krueger, A. B., And L. H. Summers (1987): "Reflections on the Inter-Industry Wage Structure," Working Paper 1968, National Bureau of Economic Research.

Kuhn, P., And M. Skuterud (2002): "Internet Job Search and Unemployment Durations," IZA Discussion Papers 613, Institute for the Study of Labor (IZA).

(2004): "Internet Job Search and Unemployment Durations," American Economic Review, 94(1), 218-232.

LEntz, R. (2009): "Optimal Unemployment Insurance in an Estimated Job Search Model with Savings," Review of Economic Dynamics, 12(1), 37-57. 
Lentz, R., and T. Tranas (2005): "Job Search and Savings: Wealth Effects and Duration Dependence," Journal of Labor Economics, 23(3), 467-490.

Lollivier, S. (1994): "Unemployment duration and business cycle," Working Paper, INSEE-CREST, Paris.

Magnac, T. (1994): "State Dependence and Heterogeneity in Youth Employment Histories," Working Paper, INSEE-CREST, Paris.

Meyer, B. D. (1990): "Unemployment Insurance and Unemployment Spells," Econometrica, 58(4), 757-82.

Saunders, C., And D. Marsden (1981): Pay Inequalities in the European Communities. London: Buttersworth, Sevenoaks.

Solaz, A. (2005): "Division of Domestic Work: Is There Adjustment Between Partners when One is Unemployed?," Review of Economics of the Household, 3(4), 387-413.

van den Berg, G. J., and B. van Der KlaAuw (2001): "Combining Micro and Macro Unemployment Duration Data," Journal of Econometrics, 102(2), 271-309.

Waite, L. J. (1995): "Does Marriage Matter?," Demography, 32(4), 483-507. 